Pacific Northwest

National Laboratory

Operated by Battelle for the

U.S. Department of Energy

\section{RONDE Ultrasonic Examination of Double-Shell Tank 241-AP-101 Knuckle Region Examination Completed April 2003}

\author{
AF Pardini \\ GJ Posakony
}

May 2003

\footnotetext{
Prepared for the U.S. Department of Energy under Contract DE-AC06-76RL01830
} 


\title{
DISCLAIMER
}

This report was prepared as an account of work sponsored by an agency of the United States Government. Neither the United States Government nor any agency thereof, nor Battelle Memorial Institute, nor any of their employees, makes any warranty, express or implied, or assumes any legal liability or responsibility for the accuracy, completeness, or usefulness of any information, apparatus, product, or process disclosed, or represents that its use would not infringe privately owned rights. Reference herein to any specific commercial product, process, or service by trade name, trademark, manufacturer, or otherwise does not necessarily constitute or imply its endorsement, recommendation, or favoring by the United States Government or any agency thereof, or Battelle Memorial Institute. The views and opinions of authors expressed herein do not necessarily state or reflect those of the United States Government or any agency thereof.

\author{
PACIFIC NORTHWEST NATIONAL LABORATORY \\ operated by \\ BATTELLE \\ for the \\ UNITED STATES DEPARTMENT OF ENERGY \\ under Contract DE-AC06-76RL01830
}

Printed in the United States of America

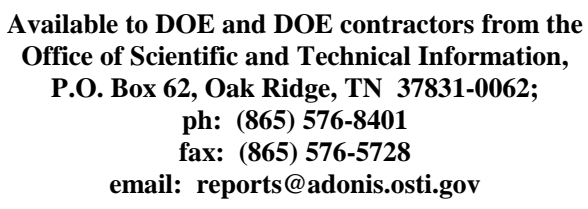

Available to the public from the National Technical Information Service, U.S. Department of Commerce, 5285 Port Royal Rd., Springfield, VA 22161 ph: (800) 553-6847 fax: $(703) 605-6900$

email: orders@ntis.fedworld.gov

online ordering: http://www.ntis.gov/ordering.htm 


\section{Summary}

COGEMA Engineering Corporation (COGEMA), under a contract from CH2M Hill Hanford Group (CH2M Hill), has performed an ultrasonic examination of the knuckle region of Double-Shell Tank 241AP-101 utilizing the Remotely Operated Nondestructive Examination (RONDE) system (also known as the SAFT/TSAFT system) (Pardini et al. 2001). The purpose of this examination was to provide information that could be used to evaluate the integrity of the knuckle region of the primary tank. The requirements for the ultrasonic examination of Tank 241-AP-101 were to detect, characterize (identify, size, and locate), and record measurements made of any circumferentially oriented cracks that might be present in the knuckle area of the primary tank. Any measurements that exceed the requirements set forth in the Engineering Task Plan (ETP), RPP-11832 (Jensen 2002), are reported to CH2M Hill and the Pacific Northwest National Laboratory (PNNL) for further evaluation. Under the contract with $\mathrm{CH} 2 \mathrm{M}$ Hill, all data is to be recorded on disk and paper copies of all measurements are provided to PNNL for third-party evaluation. PNNL is responsible for preparing a report(s) that describes the results of the COGEMA ultrasonic examinations.

\section{Examination Results}

The results of the ultrasonic examination of the knuckle region of Tank 241-AP-101 provided by COGEMA have been evaluated by PNNL personnel. The results of the examination of Tank 241-AP-101 indicated no circumferential crack-like indications were present anywhere in the knuckle region between the upper knuckle weld and the lower knuckle weld over the approximately 240 circumferential inches scanned. 


\section{Contents}

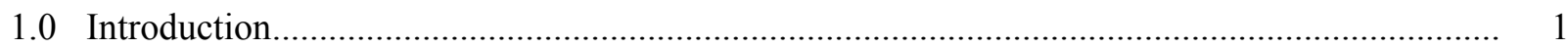

2.0 Qualified Personnel, Equipment, and Procedures................................................................ 1

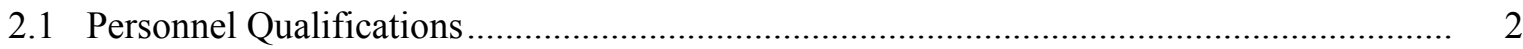

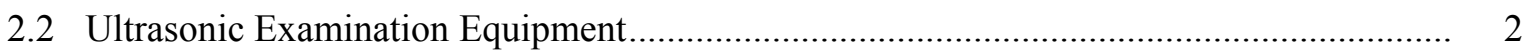

2.3 Ultrasonic Examination Procedure ................................................................................ 2

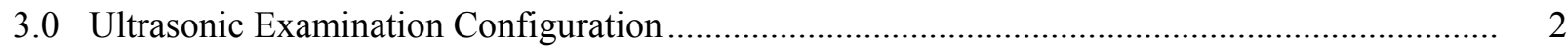

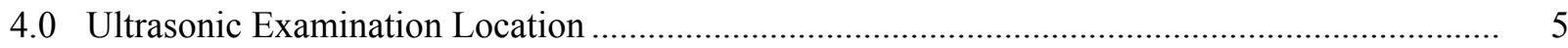

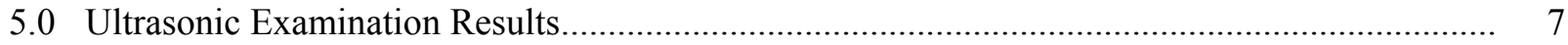

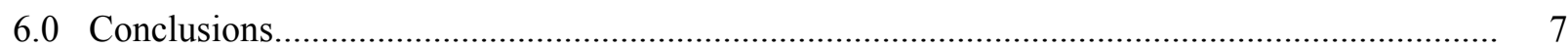

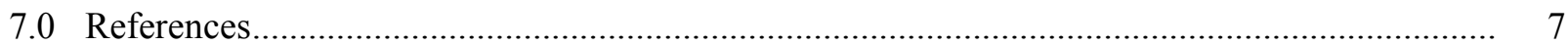




\section{Figures}

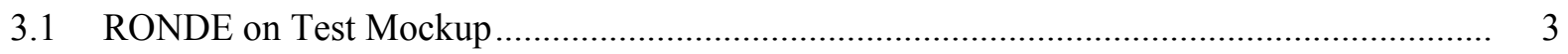

3.2 General Knuckle Scanning Arrangement...................................................................... 4

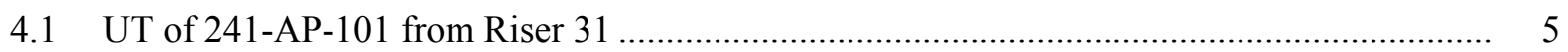

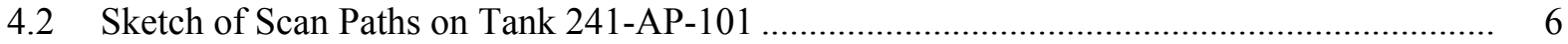




\subsection{Introduction}

COGEMA Engineering Corporation (COGEMA), under a contract from CH2M Hill Hanford Group (CH2M Hill), has performed an ultrasonic examination (UT) of selected portions of Double-Shell Tank (DST) 241-AP-101 utilizing the Remotely Operated Nondestructive Examination (RONDE) system (also known as the SAFT/TSAFT system) (Pardini et al. 2001). The purpose of this examination was to provide information that could be used to evaluate the integrity of the knuckle region of the DST. The requirements for the UT of Tank 241-AP-101 were to detect, characterize (identify, size, and locate), and record measurements made of any circumferentially oriented cracks that might be present in the knuckle area of the primary tank. Any measurements that exceed the requirements set forth in the Engineering Task Plan (ETP), RPP-11832 (Jensen 2002), are reported to CH2M Hill and the Pacific Northwest National Laboratory (PNNL) for further evaluation. Specific measurements that are reported include the following:

- Circumferentially oriented stress-corrosion cracks that exceed 0.10 in. (through-wall) that are detected in the inner wall of the tank knuckle.

The accuracy requirements for ultrasonic measurements are as follows:

- Cracks - size the depth of cracks on the inner wall surfaces within \pm 0.1 in.

- Location - locate all reportable indications within \pm 1.0 in.

Under the contract with CH2M Hill, all data is to be recorded on disk and paper copies of all measurements are provided to PNNL for third-party evaluation. PNNL is responsible for preparing a report(s) that describes the results of the COGEMA UT.

\subsection{Qualified Personnel, Equipment, and Procedures}

Under contract from $\mathrm{CH} 2 \mathrm{M}$ Hill, qualification of personnel participating in the DST inspection program, the UT equipment (instrument and mechanical scanning fixture), and the UT procedure that will be used in the examination of the current DST is required. Personnel participating in the examinations are to be certified in accordance with American Society for Nondestructive Testing (ASNT) Guideline SNT-TC-1A-92 and associated documentation is to be provided. The capability of the UT system, including personnel and procedures, is to be validated through a Performance Demonstration Test (PDT) on a mock-up simulating the actual DST. The current procedure for the UT is to be based on the Section V, Article 4, Boiler and Pressure Vessel Code defined by the American Society for Mechanical Engineers (ASME). 


\subsection{Personnel Qualifications}

The following individual was qualified and certified to perform UT of the Hanford DST 241-AP-101 knuckle region utilizing the RONDE system:

- Mr. Wesley Nelson, ASNT Level III in UT (\#LM-1874), has been identified as COGEMA's UT Level III authority for this project. Mr. Nelson has been certified by COGEMA as a UT Level III in accordance with COGEMA procedure COGEMA-SVCP-PRC-014, latest revision. Further documentation has been provided to establish his qualifications. ${ }^{(a)}$

\subsection{Ultrasonic Examination Equipment}

CH2M Hill and PNNL have provided the UT equipment for the examination of the knuckle region of Tank 241-AP-101. This equipment consists of a Force Institute AWS-5D remote-controlled, magneticwheel crawler for transporting the PNNL RONDE scanning bridge. Ultrasonic transducers used for the examinations are commercial off the shelf. The RONDE ultrasonic system has been qualified through a PDT administered by PNNL. ${ }^{\text {(b) }}$

\subsection{Ultrasonic Examination Procedure}

COGEMA has provided the RONDE UT procedure for the examination of Tank 241-AP-101. This procedure, COGEMA-SVUT-INS-007.5, Revision 0, outlines the type of UT and mechanical equipment that are to be used as well as the types of transducers. Only angle-beam transducers are used for the examination of the knuckle region of the primary tank wall. The examination procedures include full documentation on methods for calibration, examination, and reporting. Hard copies of the SAFT/TSAFT views of all areas scanned are made available for analysis. The UT procedure requires the use of specific UT transducers for the knuckle examinations. A calibration performed before and after the examinations identifies the specific transducers used and the sensitivity adjustments needed to perform the inspection. The COGEMA UT procedure has been qualified through a PDT administered by PNNL. ${ }^{\text {(a) }}$

\subsection{Ultrasonic Examination Configuration}

COGEMA is required to inspect selected portions of the DSTs that may include the primary and secondary tank walls, the heat-affected zones of primary tank vertical and horizontal welds, and the tank knuckle and bottoms. The RONDE system has been configured to perform the examination of the knuckle region. The RONDE examination of Tank 241-AP-101 concentrated on the knuckle region from

(a) Reference: "SAFT/T-SAFT Performance Demonstration Test (PDT) (Mr. Wesley Nelson)," dated November 14, 2002.

(b) E-mail from Gerald J. Posakony to Susan L. Crawford and Allan F. Pardini, dated September 27, 2002, "SAFT-T-SAFT PDT." 
the upper knuckle weld to the lower knuckle weld (approximately 19 in. measured on the inside diameter) and extended circumferentially around the tank approximately 240 in. Figure 3.1 provides an image of the actual equipment and configuration for the examination of the knuckle region of the primary tank and the approximate location of the scanner during normal operation.

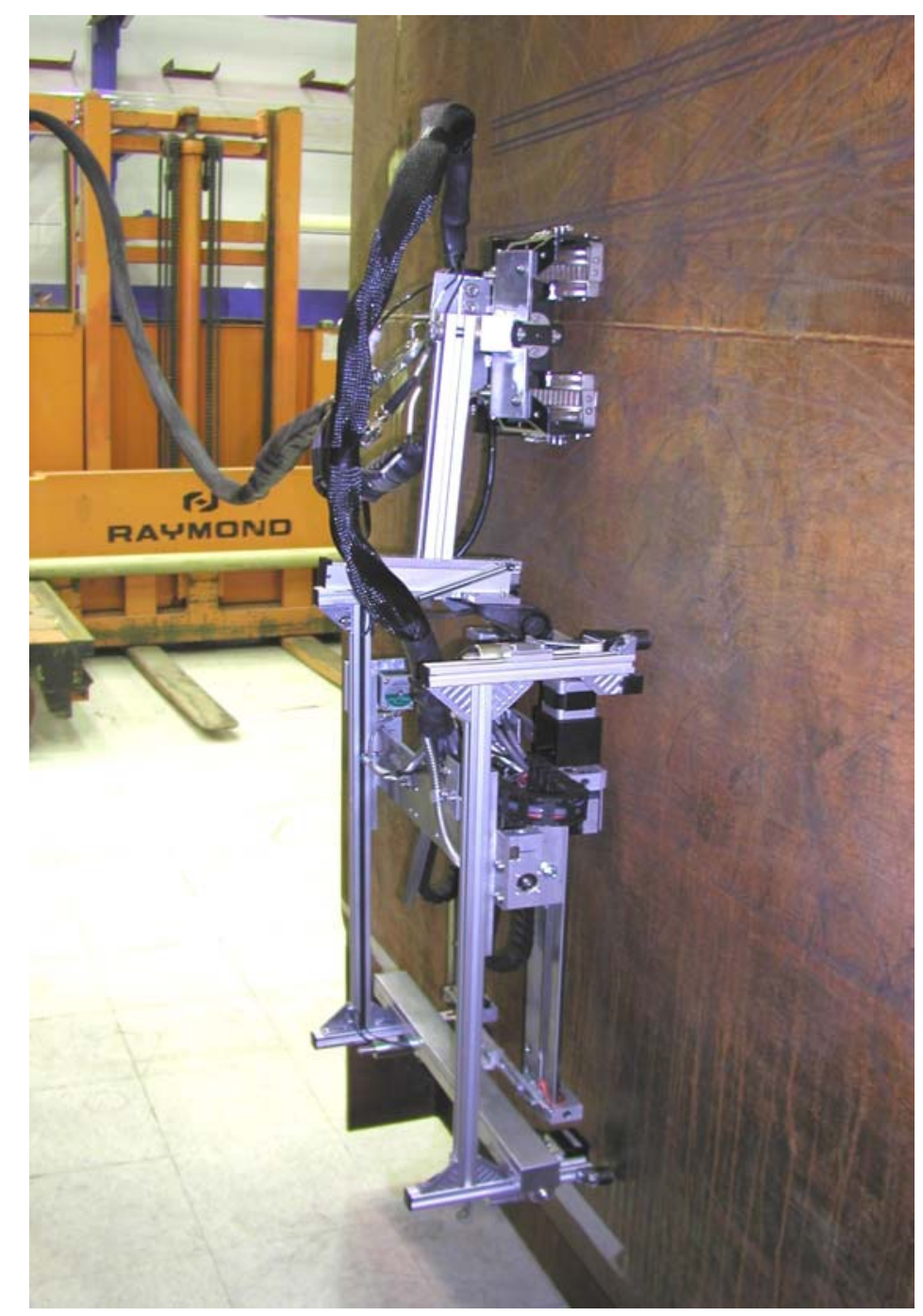

Figure 3.1 RONDE on Test Mockup

The functional diagram in Figure 3.2 shows two $70^{\circ}$ angle-beam transducers in a pitch-catch arrangement for examining the knuckle region of the primary tank. The angle beam transducers are designed to detect and record any circumferential cracking that may be present. These transducers are attached to the scanning bridge and can move together or individually. During crack detection scanning, the two transducers move together in unison, transducer A "pitching the sound" and transducer B "catching the sound." If a crack is detected, the two transducers are operated individually in a passing motion allowing for sizing of the detected crack. During detection scanning, information is captured 
every 0.025 in. (or as set by the NDE inspector) as the transducers are scanned down towards the knuckle. At the end of each scan line, the fixture is incremented 0.25 in. (or as set by the NDE inspector) and the next scan line is acquired. The mechanical scanning fixture is designed to scan the transducers approximately $10 \mathrm{in}$. by $12.5 \mathrm{in}$; however, the sound field from the $70^{\circ}$ transducer interrogates the entire volume of the knuckle and the $\mathrm{C}$-scan (plan view) display of the data shows the entire knuckle, from the upper knuckle weld to the lower knuckle weld, and 12.5 in. in circumference. This C-scan display is immediately evaluated to identify any crack-like indications which may require additional scanning for sizing. If no crack-like indication is identified in the 12.5-in. circumferential area scan of the knuckle, the crawler transports the bridge to the next area. The hard copy C-scan view provides a permanent record that can be used for any subsequent analysis.

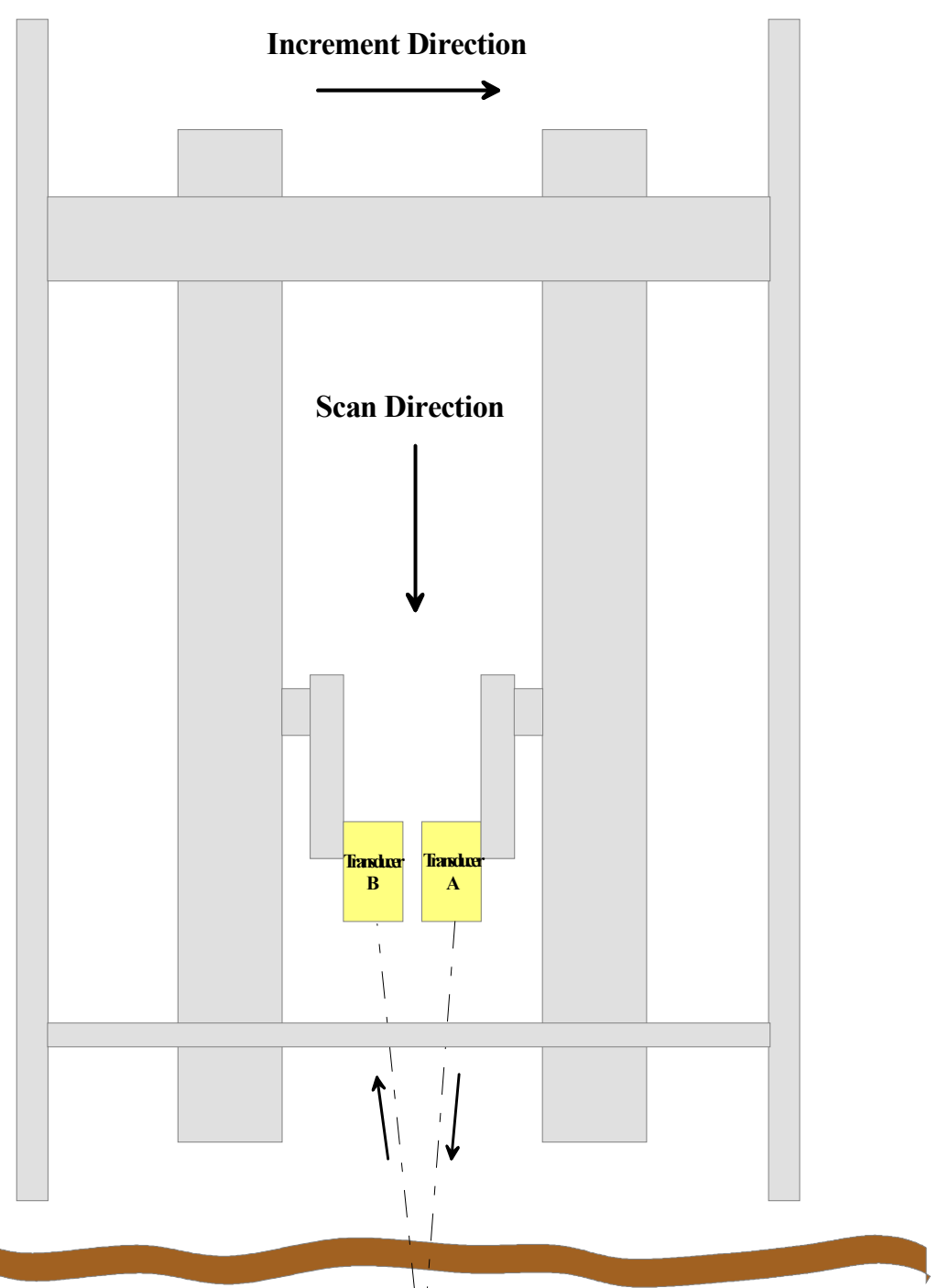

Transducer Specifications: Type: MSW-QC Benchmark Frequency: $3.5 \mathrm{MHz}$ Size: 0.5 " Diameter Angle: 70 degree, Wedge W-213 Manufacture: Krautkramer

Upper Knuckle Weld

Figure 3.2 General Knuckle Scanning Arrangement 


\subsection{Ultrasonic Examination Location}

Tank 241-AP-101 is located in the Hanford 200 East area in AP Tank Farm. The crawler and associated RONDE scanner were lowered into the 24-in. riser located on the west side of 241-AP-101 and designated as Riser 31. Riser 31 was originally called out as Riser 6 West. Figure 4.1 provides a graphic of the location of this riser. Figure 4.2 describes the area on the primary tank wall knuckle of Tank 241AP-101 that was ultrasonically examined.

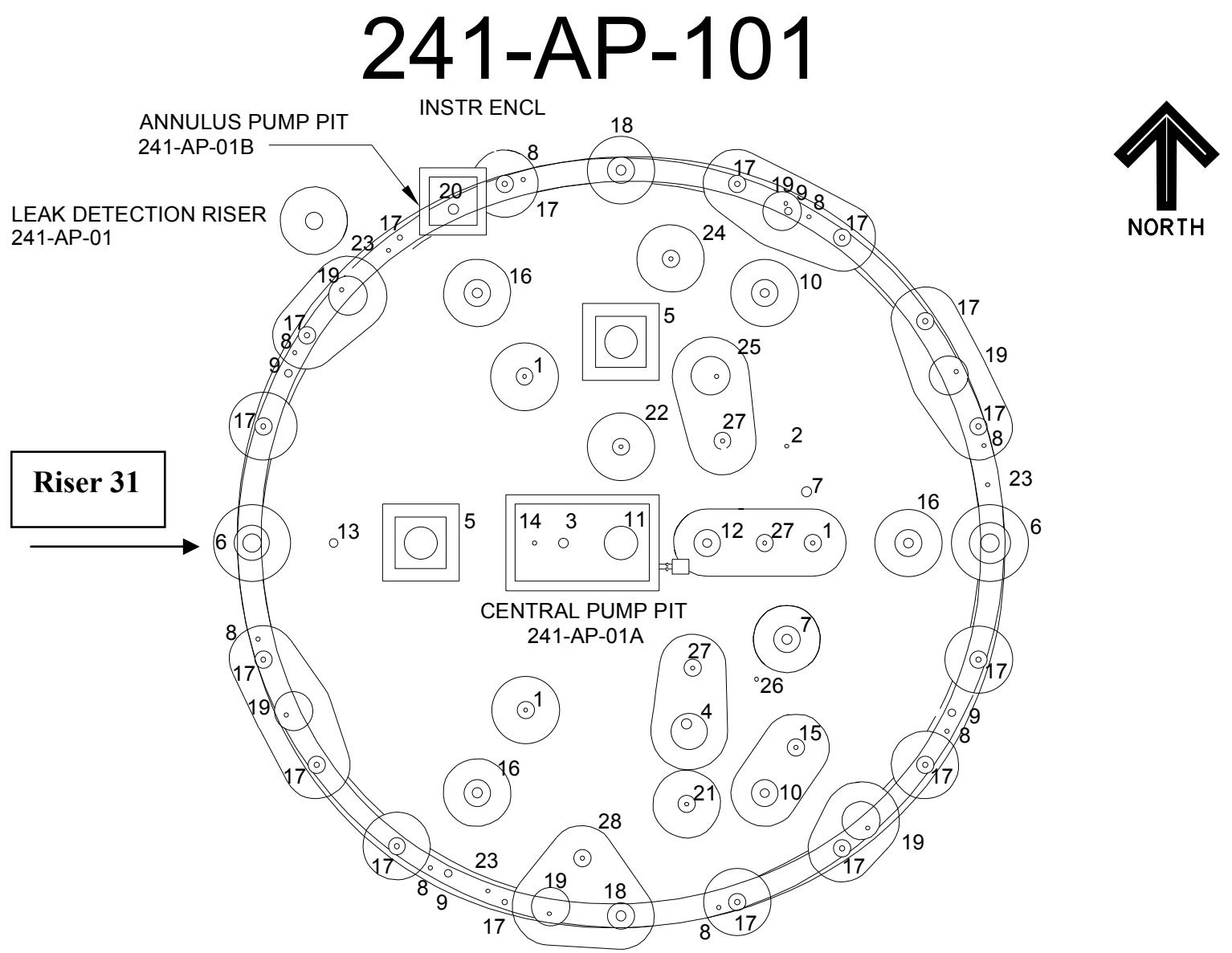

TANK RISER LOCATION

Ref: Salazar 1994

H-2-90538, Rev.1 H-2-90553, Rev.4

Figure 4.1 UT of Tank 241-AP-101 from Riser 31 


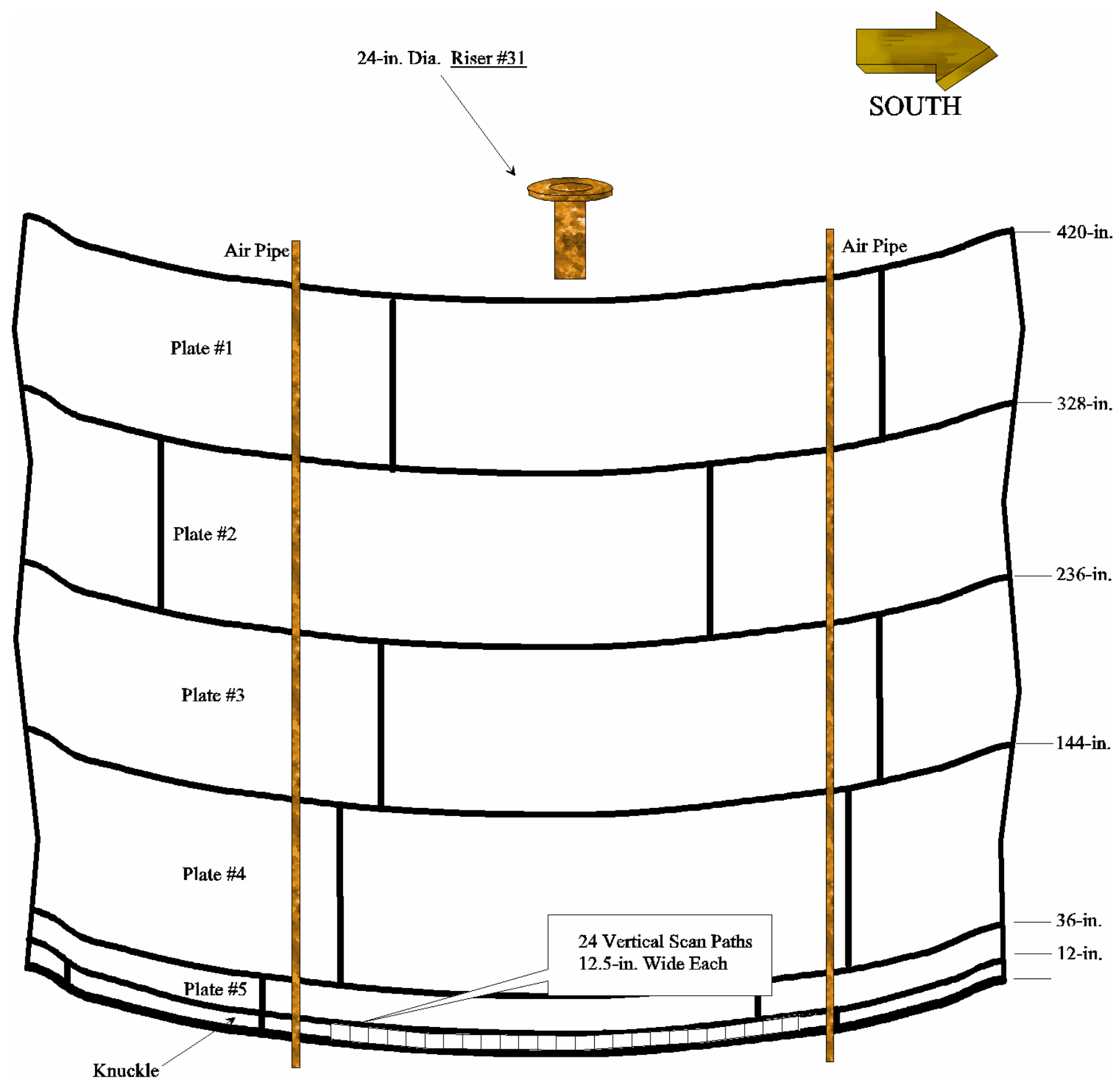

Figure 4.2 Sketch of Scan Paths on Tank 241-AP-101 


\subsection{Ultrasonic Examination Results}

COGEMA has provided detailed reports and data of all areas of the knuckle region on Tank 241-AP101 that were ultrasonically examined to PNNL for third-party review. The data was analyzed by COGEMA Level III Mr. Wes Nelson. Upon receipt of the data, PNNL staff members Susan Crawford, Jerry Posakony, and Al Pardini performed a peer review of the results.

The examination consisted of 24 individual scans, each being 12.5 in. in width (circumferential direction). The crawler was moved around the circumference in 10-in. increments, thereby providing for a 2.5-in overlap during data acquisition. The total amount of knuckle scanned was approximately 240 in. measured circumferentially around the tank. The data was displayed in a C-scan (plan) view and provided an image of the entire knuckle, from upper knuckle weld to lower knuckle weld (approximately 19 in. measured on the inside diameter), inclusive of the predicted high-stress region. Further analysis was performed on selected data files by PNNL using the SAFT analysis algorithm to verify position of the lower knuckle weld.

The results of the examination of Tank 241-AP-101 indicated no circumferential cracking was present anywhere in the knuckle region between the upper knuckle weld and the lower knuckle weld over the approximately 240 circumferential inches scanned.

\subsection{Conclusions}

The results of the examination of the knuckle region of Tank 241-AP-101 have been evaluated by PNNL personnel. The UT concentrated on the examination of the knuckle region from the upper knuckle weld to the lower knuckle weld (approximately $19 \mathrm{in}$. measured on the inside diameter) and extended circumferentially around the tank approximately $240 \mathrm{in}$. The data provided by the COGEMA Level III UT of the results of the examination of Tank 241-AP-101 indicated no circumferential crack-like indications were present in the approximately 240 circumferential inches scanned of the knuckle region.

\subsection{References}

Jensen, C. E., 2002, Engineering Task Plan for the Ultrasonic Inspection of Hanford Double-Shell Tanks FY2003, RPP-11832, Rev 0, September 2002, CH2M Hill Hanford Group, Inc., Richland, Washington.

Pardini, A. F., et al. 2001. Annual Report-Development of a Remotely Operated NDE System for Inspection of Hanford's Double Shell Waste Tank Knuckle Regions, PNNL-13682, Pacific Northwest National Laboratory, Richland, Washington. 


\section{Distribution}

No. of

Copies

\section{Offsite}

4 DOE/Office of Scientific and

Technical Information \&

Information Release

1 DOE Office of Science and

Technology

Kurt Gerdes

1154 Cloverleaf Building

19901 Germantown Road

Germantown, MD 20874-1290

\section{Onsite}

\section{Hanford Site}
J. L. Castleberry (1)
R3-76
G. P. Duncan (1)
R3-76
C. E. Jensen (2)
R3-76

10 Pacific Northwest National Laboratory
M. T. Anderson (1)
K5-26
J. W. Brothers (1)
K7-15
L. O. Casazza (1)
K5-26
S. L. Crawford (1)
K5-26
A. F. Pardini (5)
K5-26
G. J. Posakony (1)
K5-26 